\title{
CORRESPONDENCE
}

\section{Making the most of GM potatoes}

\section{To the Editor:}

The recent approval of the Amflora potato by the European Union (EU) - the EU's first registration of a genetically modified (GM) potato in 12 years-has garnered considerable media attention and public controversy. Amflora (EH92-527-1) is a GM potato produced by BASF (Ludwigshafen, Germany) that lacks amylose and instead contains amylopectin (>98\%) as the predominant $\operatorname{starch}^{1,2}$. Amylose ordinarily has to be removed to allow the industrial use of potato starch. Thus, Amflora is a highly suitable source for technical applications, such as paper, adhesive and textile production. Supporters of the technology welcome the approval, which has taken 13 years, and consider it a regulatory milestone, at least for GM potatoes. Opponents are afraid that it heralds the opening of the regulatory floodgates for more transgenic varieties. Accepting the view that the use of GM technology should be based on careful caseby-case consideration ${ }^{3}$, I see two key issues that may not be trivial and should be discussed, as they generate most of the public concern.

Amflora contains a gene encoding neomycin phosphotransferase II (NptII) that confers kanamycin resistance, and critics argue that this antibiotic resistance gene could escape via the food chain or horizontal transfer into ecosystems. The antibiotic marker is there as a selection gene and was needed to introduce the antisense construct that blocks amylose production by targeting granule-bound starch synthase (GBSS). Although horizontal transfer of transgenic traits into ecosystems is not well accepted by the scientific community, the possibility that it could happen cannot completely be excluded ${ }^{4,5}$. One way around this possibility would be simply to remove the selection gene NptII (e.g., using the Cre/loxP system ${ }^{6}$ ) in future generations. This would represent an additional burden for the breeders of GM potatoes, but it would also facilitate a second round of transformation, if needed. Most importantly of all (scientific concerns aside), an Amflora derivative lacking kanamycin resistance would have much improved public acceptance. In fact, if in subsequent years

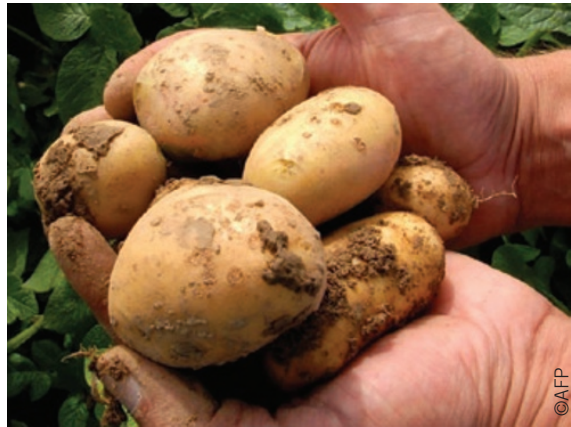

You say potato, I say Amflora. BASF recently received approval from the EU to market its GM potato engineered with reduced amylase content via an antisense construct targeting granulebound starch synthase.

Amflora were to inadvertently end up in the human food chain through admixture with potatoes grown for human consumption, the potential health risk would be diminished, as removal of the antibiotic marker would leave only the transgene, an antisense construct, which lowers the expression of an endogenous GBSS gene but has no proteincoding potential on its own.

A second concern of opponents of Amflora potatoes relates to the possibility of transgene dissemination to other potatoes. Such spreading of the transgene is unlikely, as potato transgene movement by pollen is very limited ${ }^{7}$ and escaped wild-type potatoes have rarely been observed in Europe $^{8}$. Nevertheless, these arguments again cannot be dismissed completely, as in our global world, dissemination in the long term cannot be excluded and may even be likely. As commercial potato production, especially that using GM varieties, does not require sexual reproduction, it seems reasonable to carry out gene manipulation in potato varieties in which the genes for sexual reproduction have been permanently deleted. Such a strategy would probably negate concerns relating to the spread of potato transgenes into the ecosystem.

In conclusion, with the addition of these two safety features, GM potatoes could become the standard for other transgenic crops, particularly in the European market, where outcrossing or admixture of GM crops with conventional varieties remains such a hot-button issue. Such crops would represent low-risk GM varieties, which possibly could be cleared through approval authorities in a more timely manner? For example, GM potatoes resistant to potato late blight ${ }^{10}$ that are currently being generated (http://www.gmo-safety.eu/en/ potato/plant_diseases/462.docu.html) would probably be more palatable to both the public and regulatory authorities if selection markers were removed and sexual reproduction were irreversibly blocked. Who knows: as late-blight disease caused by the pathogen Phytophthora infestans is a serious problem in the farming of organic potatoes ${ }^{11}$, sterile GM potatoes resistant to the phytopathogen might become accepted even in the organic farming community ${ }^{12}$.

\section{COMPETING FINANCIAL INTERESTS}

The author declares no competing financial interests.

\section{Gerhart U Ryffel}

Institut für Zellbiologie (Tumorforschung), Universitätsklinikum Essen, Universität

Duisburg-Essen, Germany.

e-mail:gerhart.ryffel@uni-due.de

1. EFSA. The EFSA Journal 323, 1-20 (2006)

2. EFSA. The EFSA Journal 324, 1-20 (2006).

3. Arntzen, C.J., Coghlan, A., Johnson, B., Peacock J. \& Rodemeyer, M. Nat. Rev. Genet. 4, 839-843 (2003).

4. Lemaux, P.G. Annu. Rev. Plant Biol. 59, 771-812 (2008).

5. Lemaux, P.G. Annu. Rev. Plant Biol. 60, 511-559 (2009).

6. Cuellar, W. et al. Plant Mol. Biol. 62, 71-82 (2006).

7. McPartlan, H.C. \& Dale, P.J. Transgenic Res. 3, 216 225 (1994).

8. Lauber, K. \& Wagner, G. Flora des Kantons Bern: 1836 Farbfotos der wildwachsenden Blüten- und Farnpflanzen; Artbeschreibung und Bestimmungsschlüssel (Paul Haupt, Berne, Switzerland, 1991).

9. Rommens, C.M. J. Agric. Food Chem. 55, 4281-4288 (2007).

10. Song, J. et al. Proc. Natl. Acad. Sci. USA 100, 9128 9133 (2003).

11. Dupuis, B., Rolot, J.L., Stilmant, D., Labbe, V. \& Laguesse, L. Commun. Agric. Appl. Biol. Sci. 72 353-359 (2007).

12. Ronald, P.C. \& Adamchak, R.W. Tomorrow's Table: Organic Farming, Genetics and the Future of Food (Oxford Univ. Press, New York, 2008). 